\title{
Assessment of Nutritional Status and Developing Low Cost Recipes for Malnourished Children in the Tsunami affected Areas of Nagapattinam District
}

\author{
Raja lakshmi. J1., Sheila John² \\ ${ }^{1}$ No: 532, CTH Road, Brindavan colony, Pattabiram, Chennai-72. Tamilnadu, India. \\ 'Women's Christian college, Chennai-600 006, Tamil Nadu, India.
}

\author{
A B STRACT
}

Background: The tsunami disaster in the Indian Ocean is one of the worst natural disasters in the modern times. The grief and worry created by the disaster has affected the health status of women and children. Malnutrition and ill health are major problems. This study investigated the nutritional status of the children and provided a nutrition education program for the mothers. Aims: To study the demographic profile, dietary habits, anthropometric measurements, clinical assessment, incident rates of infectious diseases among the 500 children. To assess the dietary intake of 100 malnourished children and to formulate ten low cost nutritionally balanced recipes and to provide nutrition education program for the mothers. Sample: 500 preschool children in the age group of 3-6 years of the tsunami affected Nagapattinam district were the samples of this study. Method: Interview schedule was administered to 500 mothers. Anthropometric measurements such as height, weight, mid arm circumference, head circumference and chest circumference were recorded by the investigator. Three day dietary recall method was used to assess the nutrient intake. Clinical assessment was conducted with the help of a doctor. Nutrition education was provided to the mothers with the help of posters and charts. Results: The results found that, majority of the children were under nourished and there was a significant difference between the mean nutrient intake and the recommended dietary allowance. Mean scores of nutritional knowledge and awareness significantly increased after the nutrition education program. Conclusion: Nutrition education must be provided to the mothers to improve the nutritional status of the children. The gained knowledge had to be put into practice.

Key words: Malnutrition, Tsunami, Anthropometry, dietary assessment, Nutrition education program.

\section{INTRODUCTION}

One of the greatest natural calamities of modern times, the tsunami that struck the Indian Ocean shores on the $26^{\text {th }}$ of December 2004, left over 3, 00,000 people dead, thousands injured and millions of survivors left homeless, impoverished and psychologically scared forever. The tsunami disaster in the Indian Ocean is one of the worst natural disasters in the recent times which have affected Indonesia, India, the Maldives, Somalia, Sri lanka and Thailand. In India, the state of Tamilnadu has been the worst affected on the mainland with a death toll of 7,793. Nagapattinam has had 5,525 causalities with entire villages

Address for correspondence:

E-mail: raji_pals@yahoo.co.in; smiley.rajee@gmail.com; vs.sheila@gmail.com

DOI: 10.5530/ijmedph.2.2011.15 having been destroyed. Beyond the death toll, the tsunami of $26^{\text {th }}$ December 2004 crippled many of their livelihood assets such as human, social, physical, financial and natural resources. ${ }^{1}$

Following the disaster, there are even higher rates of epidemic and endemic diseases, and the nutritional status is declining. Communicable diseases are an increasing threat and there is almost a complete lack of basic social services. Provision of safe drinking water, toilet facilities and water supply, waste water and sewage systems management is unsatisfactory Malnutrition, diarrheal diseases, measles, acute respiratory infections, cholera, diphtheria, dysentery and typhoid depression, stress disorder pose a threat to public health. World Health Organization warned about the increased risk of vector-borne diseases such as malaria and dengue fever across tsunami- affected areas in Southeast Asia. 2

The initial phase of the disaster was marked by limited access to food, coupled with an inadequate supply of safe 
water and poor environmental hygiene, and sanitation, all of which placed children at increased risk for under nutrition.3

Malnutrition increases dramatically and kills most rapidly in emergencies. Most children do not die due to conflicts or natural disasters themselves, but rather to resulting food shortages, lack of proper nutrition and poor sanitation and hygiene. The vast majority of children succumb to measles, diarrhea, and severe malnutrition.

The diversity of the problems experienced in long and short term refugee situations demands a diversity of approaches in nutrition, skill development, income generation, disease surveillance, control and prevention. Hence the present study was planned to assess the nutritional and health status of children in the tsunami affected Nagapattinam district and provide low cost recipes, nutrition education program for the parents to ensure their rehabilitation form the deadly disaster.

\section{OBJECTIVES}

1. (a) To study the demographic profile, dietary habits, socio-economic status, anthropometric measurements and indices and clinical assessment of the 500 children. (b) To determine the incident rates of diseases that have public health importance like malaria, respiratory tract infections, water and food borne diseases and diarrhea among the 500 children

2. To assess the dietary intake of the 100 malnourished children.

3. To formulate and standardize ten low cost nutritionally balanced recipes for the malnourished children.

4. To formulate, conduct and assess the impact of a comprehensive nutrition education program for the mothers and their children.

\section{METHODOLOGY}

This study was carried out in three phases.

Phase I - In the first phase of the study, 500 children of the age group 3-6 years in the tsunami affected areas of Nagapattinam district were randomly selected to study the risk factors prevalent that predispose a child to malnutrition. An interview schedule was used to elicit the information from the mothers of these children regarding the demographic profile; socio-economic status; dietary patterns; food habits; meal patterns; food availability and food preparation. Anthropometric measurements such as height, weight, mid-arm circumference, head circumference and chest circumference are recorded. Clinical assessment will be conducted with the help of a doctor to assess the presence of symptoms of malnutrition in relation to hair, eyes, ear, mouth, skin, nails, legs, growth retardation and oedema.

Phase II - In the second phase of the study, from the initial sample size of 500 children, a subsample of 100 malnourished children were selected to record the dietary intake for 3 days. Ten low cost nutritionally balanced recipes were formulated and standardized for the children. and sensory evaluation was conducted for the recipes by the panel members. The panel members were the twenty mothers of the children who are willing to evaluate the recipes.

Phase III - A nutrition education program was formulated and conducted and for all the mothers of the 100 malnourished children, and to train the mothers on raising environmental awareness by improving sanitation facilities, encouraging energy efficiency and advantages of having a kitchen garden. Income generation and skill training formed an important component of the program. The income generating skills such as preparation of pickles using the locally available fish and prawn were taught to them. Squash preparation from citrus fruits such as lemon and oranges were demonstrated to the mothers of the preschool children. Jewelry making from the sea shells was also taught to them as a part of income generating skill program. Individual counseling for preschool children, protein-energy malnutrition- causes consequences and preventive measures; were provided to the mothers of the preschool children. The impact of nutrition education program for the mothers of these children in terms of knowledge and awareness was assessed in the third phase of the study.

\section{RESULTS AND DISCUSSION}

Malnutrition, one of the poverty's cruel partner takes many forms and causes. It is one of the most important nutritional problems among the developing countries. Hence the present study was undertaken to identify malnourished children through a survey of 500 preschool children from the tsunami affected areas of Nagapattinam district A comparison of the anthropometric measurements, signs and symptoms of malnutrition from the clinical assessment and the nutritional status of the preschool boys and girls were also done. A sub sample of 100 malnourished children was selected at random from 500 children to study their dietary intake using a three day dietary recall.

Results of the survey of 500 children revealed that majority of the children were in the age group of 5 to 6 years. A large percent of the mothers of boys and girls were housewives. Highest percentage of both boys and girls were belonging to the low income group. 
A higher percent of boys and girls reported suffering from diarrhea and chickungunya after the attack of tsunami compared to other ailments. Dengue and diphtheria were not reported by any of the children while around 37 percent of boys and girls reported having respiratory tract infections. Chickungunya was one of the epidemic outbreaks affecting more than 50 percent of the population. Chickungunya fever is a viral illness that is spread by the bite of infected mosquitoes. The disease resembles dengue fever is characterized by severe and sometimes persistent joint pain (arthritis) as well as fever and rash. ${ }^{4}$ Post tsunami victims presented themselves with mixed infections of tuberculosis, meliodosis and many bacterial or fungic infections affecting the pulmonary tract, the skin and the injured soft tissues. These later infections were due to rare or a typical frequently multiresistant microorganisms. The results of the current study supported this finding. ${ }^{5}$

\section{General appearance}

Clinical examination of the children revealed that about 43 percent of boys and girls appeared normal while 40.5 percent of boys and 41.0 percent of girls were undernourished. 13 Percent boys and 14.6 percent girls were malnourished. This shows that gender have a great influence on nourishment of the child and generally girls were more prone to be malnourished than boys. ${ }^{6}$ The results of present study was also in line with this study

\section{Hair}

In protein energy malnutrition hair becomes thin and sparse, lacks luster and is depigmented, easily plucakable signs appear. In the present study 34.5 percent of boys and 36.7 percent boys reported of thin and sparse hair. 27 to 32 percent dispigmented and easily pluckable hair indicator of malnutrition. The results of the current study are also supportive to the earlier studies.

\begin{tabular}{|c|c|c|c|c|c|}
\hline \multicolumn{2}{|c|}{ Particular } & \multicolumn{2}{|c|}{ Boys $(n=252)$} & \multicolumn{2}{|c|}{ Girls $(n=248)$} \\
\hline & & Number & Percent & Number & Percent \\
\hline \multirow[t]{8}{*}{ Occurrence of diseases after tsunami } & Diarrhea & 166 & 65.9 & 177 & 71.4 \\
\hline & Typhoid & 31 & 12.3 & 62 & 25.0 \\
\hline & Malaria & 13 & 5.2 & 14 & 5.6 \\
\hline & Respiratory tract infections & 93 & 36.9 & 94 & 37.9 \\
\hline & Chickungunya & 196 & 77.8 & 173 & 69.8 \\
\hline & skin allergy & 36 & 14.3 & 17 & 6.9 \\
\hline & Fever, cold \& cough & 43 & 17.1 & 36 & 14.5 \\
\hline & Nausea \& vomiting & 30 & 11.2 & 8 & 3.2 \\
\hline
\end{tabular}

\begin{tabular}{|c|c|c|c|c|c|}
\hline \multicolumn{2}{|c|}{ Particular } & \multicolumn{2}{|c|}{ Boys $(n=252)$} & \multicolumn{2}{|c|}{ Girls $n=248$ ) } \\
\hline & & Number & Percent & Number & Percent \\
\hline \multirow[t]{4}{*}{ General Appearance } & Normal & 111 & 44.0 & 108 & 43.5 \\
\hline & Obese & 5 & 2.0 & 1 & 0.4 \\
\hline & Undernourished & 102 & 40.5 & 103 & 41.5 \\
\hline & Malnourished & 34 & 13.5 & 36 & 14.6 \\
\hline \multirow[t]{5}{*}{ Hair } & Normal & 69 & 27.4 & 76 & 30.6 \\
\hline & Dry & 83 & 32.9 & 71 & 26.6 \\
\hline & Dispigmented & 72 & 28.6 & 65 & 26.2 \\
\hline & Thin and sparse & 87 & 34.5 & 91 & 36.7 \\
\hline & Easily Pluckable & 71 & 28.2 & 67 & 27.0 \\
\hline \multirow[t]{6}{*}{ Eyes } & Normal & 214 & 84.9 & 210 & 84.7 \\
\hline & Pale conjunctiva & 13 & 5.2 & 18 & 7.3 \\
\hline & Conjuctival xerosis & 14 & 5.5 & 9 & 3.6 \\
\hline & Bitot's spot & 8 & 3.2 & 10 & 4.0 \\
\hline & Keratomalacia & 3 & 1.2 & 0 & 0 \\
\hline & Night Blindness & 0 & 0 & 1 & 0.4 \\
\hline \multirow[t]{3}{*}{ Lips } & Normal & 152 & 60.3 & 151 & 60.9 \\
\hline & Angular stomatitis & 58 & 23.0 & 56 & 22.6 \\
\hline & Angular scars & 42 & 16.7 & 41 & 16.5 \\
\hline \multirow[t]{4}{*}{ Tongue } & Normal & 211 & 83.7 & 210 & 84.8 \\
\hline & Atrophic papillae & 17 & 6.7 & 15 & 6.0 \\
\hline & Fissures & 13 & 5.2 & 14 & 5.6 \\
\hline & Abnormally smooth & 11 & 4.4 & 9 & 3.6 \\
\hline
\end{tabular}




\section{Eyes}

A majority of 84 percent had eyes that appear normal. 5 percent of the boys had pale conjunctiva and conjunctival xerosis, while 7.3 and 3.6 percent of girls had pale conjunctiva and conjunctival xerosis respectively. None of the boys had night blindness while none of the girls had keratomalacia.

\section{Lips}

60 percent of boys and girls had normal lips while 23 percent of boys and girls and 16.5 percent of boys and girls had angular stomatitis and angular scars respectively. The result of the current study was in line with a study conducted by Singh et al, ${ }^{7}$ which revealed that chronic energy deficiency is associated with Vitamin A deficiency, Vitamin B complex deficiency, angular stomatitis, cheilosis and glossitis.

\section{Tongue}

A majority of 83 to 84 percent of boys and girls had tongue that appears normal. 6 to 7 percent of boys and girls had atrophic papillae and 5 percent of them have presence of fissures.

The percent distribution of boys and girls based on the clinical assessment related to gums, neck glands, skin, nails, oedema and rachitic changes is presented in table 3

\section{i. Gums}

With regard to the clinical assessment of gums, majority of 80.2 percent and 87.1 percent girls had normal gums 19.8 percent of boys and 12.9 percent of girls had bleeding gums. Bleeding gums is usually due to deficiency of Vitamin C commonly found in malnourished children.

\section{ii. Neck glands}

Majority of boys and girls had normal neck glands while only 1.2 percent of boys and 0.4 percent of the girls had enlarged neck glands.

\section{iii. Skin}

A higher percentage of above 76 percent of boys and girls had normal skin. From table 15, it is evident that 13.5 percent boys and 19.0 percent girls were found to have dry skin. Phrynoderma was present only in 0.4 percent of boys. Phrynoderma is the hyperkeratanisation of the epithelium lining the follicle. The skin becomes rough, dry and papules of varying size arising at the site of pilosebaceous follicles. Recent evidence suggests that the skin changes of kwashiorkor may be caused by zinc deficiency. ${ }^{8}$ Skin changes in protein energy malnutrition may involve any part of the body, the more common sites being lower limbs, buttocks and perineum. The skin changes show characteristic areas of desquamation and pigmentation or depigmentation. Cracks appear as folds and ulcers may develop at anal region and over pressure joints. ${ }^{9}$

\section{iv. Nails}

Majority of the children above 93 percent in both groups had normal nails. One of the classic symptom of protein energy malnutrition is koilonychia. This is a condition where the nails are spoon shaped, hard and brittle, this occurs due to deficiency of iron in the body. (Mc claren, 1987)In the present study 4.4 percent of boys and 6.9 percent of girls had this condition.

\begin{tabular}{|c|c|c|c|c|c|}
\hline \multicolumn{2}{|c|}{ Particular } & \multicolumn{2}{|c|}{ Boys $(n=252)$} & \multicolumn{2}{|c|}{ Girls $(n=248)$} \\
\hline & & Number & Percent & Number & Percent \\
\hline \multirow[t]{2}{*}{ Gums } & Normal & 202 & 80.2 & 216 & 87.1 \\
\hline & Bleeding & 50 & 19.8 & 32 & 12.9 \\
\hline \multirow[t]{2}{*}{ Neck glands } & Normal & 249 & 98.8 & 247 & 99.6 \\
\hline & Enlarged & 3 & 1.2 & 1 & 0.4 \\
\hline \multirow[t]{4}{*}{ Skin } & Normal & 208 & 79.8 & 193 & 76.2 \\
\hline & Dry & 34 & 13.5 & 47 & 19.0 \\
\hline & Follicular hyperkeratosis & 9 & 3.6 & 7 & 2.8 \\
\hline & Phrynoderma & 1 & 0.4 & 0 & 0 \\
\hline \multirow[t]{2}{*}{ Nails } & Normal & 241 & 95.6 & 231 & 93.1 \\
\hline & Koilonychia & 11 & 4.4 & 17 & 6.9 \\
\hline \multirow[t]{2}{*}{ Oedema } & Present & 14 & 5.6 & 17 & 6.9 \\
\hline & Absent & 238 & 94.4 & 231 & 93.1 \\
\hline \multirow[t]{4}{*}{ Rachitic changes } & Normal & 242 & 96.0 & 225 & 90.8 \\
\hline & Knock knees & 5 & 2.0 & 10 & 4.0 \\
\hline & Bow's legs & 4 & 1.6 & 6 & 2.4 \\
\hline & Pigeons chest & 1 & 0.4 & 7 & 2.8 \\
\hline
\end{tabular}




\section{v. Oedema}

There is the presence of oedema due to hyponatremia. In the present study 5.6 percent of the boys and 6.9 percent of girls had oedema with majority of them found to have oedema in legs and face

\section{vi. Rachitic changes}

This includes knock knees, bow legs and pigeon's chest. 96 percent and 90 percent of boys and girls did not have any changes in the legs a while a smaller percent of boys and girls showed the presence of rachitic changes.

Table 4 compares the grades of malnutrition between boys and girls based on Indian Academy of Pediatrics classification of weight for age ${ }^{10}$

24.6 percent of boys and 14.1 percent of girls were categorized to be grade I malnourished children. 16.3 percent boys and 15.7 percent girls were grade II malnourished. 4.4 percent girls and 4.0 percent boys were severely malnourished and categorized as grade IV malnourished children. A significantly higher proportion was found to be present among female children of higher birth order and those belonging to families with lower per capita income compared to males. Caretakers are generally gender biased and concerned more about male children during feeding and so female children are highly malnourished compared to males. ${ }^{11}$ The overall results of the present study were highly supportive to this study.

Statistics pertaining to anthropometric measurements such as height, body weight, mid arm circumference, chest circumference and head circumference are presented and discussed in this section. The mean values of the anthropometric measurements and results of test of significance of boys and girls are provided in this section.

Table 5 provides the statistics pertaining to the comparison of mean anthropometric measurements such as height, body weight, mid arm circumference, head circumference and chest circumference of boys and girls.

\section{Height}

Height measurements were taken at the beginning of the study. It was observed that the mean height for boys was $95.39 \mathrm{~cm}$ and the mean height for girls was $93.76 \mathrm{~cm}$. The difference in height was not significant between two groups. During periods of severe deprivation, linear growth rate slows down and leads to stunting. ${ }^{12}$ Thus stunting is a consequence of chronic food deficiency.

\section{Body Weight}

The mean body weight observed for the boys were 13.82 $\mathrm{Kg}$ and for the girls was $13.16 \mathrm{~kg}$. The difference in weight was significant at 1 percent level between the two groups. This is due to the higher nutrient intake of boys when compared to girls. A significantly higher proportion of malnutrition was found to be present among female children of higher birth order and those belonging to families with lower per capita income compared to males. Caretakers are generally gender biased and concerned more about male children during feeding and so female children are highly malnourished compared to males. ${ }^{11}$

\section{Mid arm circumference}

The mean values of mid arm circumference of both boys and girls was $14.33 \mathrm{Cm}$ and $14.34 \mathrm{~cm}$ respectively. There

Table 4: Comparison of grades of malnutrition between boys and girls

\begin{tabular}{llccccc}
\hline Particular & & \multicolumn{2}{c}{ Boys $(\boldsymbol{n = 2 5 2 )}$} & \multicolumn{2}{c}{ Girls $(\boldsymbol{n}=\mathbf{2 4 8})$} & \multicolumn{2}{c}{$\begin{array}{c}\text { Chi } \\
\text { square } \\
\text { Value }\end{array}$} & $\begin{array}{c}\text { Level of } \\
\text { significance }\end{array}$ \\
\cline { 3 - 6 } & Number & Percent & Number & Percent & 5.595 & $5 \%$ \\
\hline Grades of malnutrition & Normal & 122 & 48.4 & 141 & 56.9 & \\
& Grade I & 62 & 24.6 & 35 & 14.1 & \\
& Grade II & 41 & 16.3 & 39 & 15.7 & \\
& Grade III & 17 & 6.7 & 22 & 8.9 & \\
& Grade IV & 10 & 4.0 & 11 & 4.4 & \\
\hline
\end{tabular}

Table 5: Comparison of mean anthropometric measurements of boys and girls

\begin{tabular}{|c|c|c|c|c|c|c|c|c|}
\hline \multirow[t]{2}{*}{ Anthropometry } & \multicolumn{3}{|c|}{ Boys $(n=252)$} & \multicolumn{3}{|c|}{ Girls ( $n=248)$} & \multirow[t]{2}{*}{ 't'Value } & \multirow{2}{*}{$\begin{array}{c}\text { Level of } \\
\text { significance }\end{array}$} \\
\hline & Mean & S.D & S.E & Mean & S.D & S.E & & \\
\hline Height (cm) & 95.39 & 9.730 & 0.613 & 93.76 & 9.947 & 0.632 & 1.856 & NS \\
\hline Body weight (kg) & 13.82 & 2.686 & 0.169 & 13.16 & 2.582 & 0.164 & 2.827 & $1 \%$ \\
\hline Mid arm circumference $(\mathrm{cm})$ & 14.33 & 1.857 & 0.117 & 14.34 & 1.825 & 0.116 & 0.020 & NS \\
\hline Head circumference (cm) & 48.52 & 1.602 & 0.101 & 47.78 & 1.894 & 0.120 & 4.745 & $1 \%$ \\
\hline Chest circumference $(\mathrm{cm})$ & 49.77 & 2.321 & 0.113 & 49.17 & 2.337 & 0.148 & 2.911 & $1 \%$ \\
\hline
\end{tabular}

S.D. - Standard deviation

NS - Not significant

S. E. - Standard error of mean 
was no significant difference in the mean values for mid arm circumference between the groups. Measurement of mid arm circumference is a useful method of assessing malnutrition The reference standard of mid arm circumference for 1 to 5 years old children is 15 to $17 \mathrm{~cm} .{ }^{13}$

\section{Head circumference}

Mean head circumference measurements of the boys was $48.2 \mathrm{~cm}$ whereas mean head circumference of girls was $47.72 \mathrm{~cm}$ There was a significant difference that is at 1 percent level between the two groups. Head size relates mainly to the size of brain which increases rapidly during infancy.

\section{Chest circumference}

The mean value of chest circumference of boys and girls was $49.77 \mathrm{~cm}$ and $49.17 \mathrm{~cm}$ respectively. There was a significant difference at 1 percent level between boys and girls for chest circumference. In protein energy malnutrition in poor children, due to poor growth of chest, the head circumference may remain to be higher than the chest at the age $2 \frac{1}{2}$ to 3 years. The result of the present study is also in line with this study. ${ }^{14}$

\section{Nutrient intake}

Comparison of mean nutrient intake with the Recommended Dietary Allowances ${ }^{15}$ is presented in table 6. The mean nutrient intake for energy and iron was lower than the Recommended Dietary Allowance while the mean nutrient intake of protein, fat and calcium was much higher than the Recommended Dietary Allowance. The decreased intake of energy compared to the Recommended Dietary Allowance was significant at 1 percent level. The high intake of protein and calcium may be contributed to the excess consumption of fish due to the availability. Fish is a good source of calcium. Most fish contain 15 to 24 percent protein, 0.1 to 0.22 percent fat and 0.8 to 2 percent minerals. Fish also contains omega -3 poly unsaturated fatty acids which are known to protect against cardiovascular diseases. ${ }^{16}$

\section{Nutrition Education}

Nutrition education is a means of helping people to help themselves to improve or maintain their health. It is an important step in the process of providing health care. Nutrition education program was conducted for the mothers of the preschool children emphasizing the importance of nutrition to prevent protein energy malnutrition. Charts, posters and power point presentation were used for the nutrition education program.

An initial assessment of the knowledge and awareness of the preschool mothers was carried out using a checklist. The checklist contained twenty questions pertaining to the knowledge and awareness of the mothers on importance of nutrition and prevention of protein energy malnutrition.

Comparison of mean value of pretest and post test scores of awareness and knowledge of mothers of preschool children revealed that, there was a significant difference at 1 percent level between pre test and post test. Thus the nutrition education program has helped to improve the awareness and knowledge of the mothers of the preschool children

\section{SUMMARY AND CONCLUSION}

Protein energy malnutrition is the most wide spread from of malnutrition among preschool children of our country. Children residing in urban slums were more malnourished when compared to other children. Children and women were most affected by malnutrition after a natural disaster. Nutrition intervention program including individual counseling to the mothers of the preschool children and the demonstration of low cost recipes from the locally available foods will help them to prevent the onset of protein energy malnutrition. The income generating skills will help the mothers support their family financially and to sustain their lives

\section{REFERENCES}

1. Asian Tsunami Disaster Report - 2004.

2. Jayatissa et al. Assessment of Nutritional Status of Children under Five Years of Age, Pregnant Women and Lactating Women Living in Relief Camps after the Tsunami in Sri Lanka. Food Nutr. Bull. 2006; 27(2):144-52.

\begin{tabular}{|c|c|c|c|c|c|c|}
\hline \multirow[t]{2}{*}{ Nutrients } & \multirow[t]{2}{*}{ RDA } & \multicolumn{3}{|c|}{ Children aged 4-6 years $(N=80)$} & \multirow[t]{2}{*}{ 't' value } & \multirow{2}{*}{$\begin{array}{c}\text { Level of } \\
\text { significance }\end{array}$} \\
\hline & & Mean & S.D & S.E & & \\
\hline Energy (Kcal) & 1690 & 1011 & 188.89 & 20.61 & 3.572 & $1 \%$ \\
\hline Protein (g) & 30 & 61.82 & 129.03 & 14.07 & 0.245 & NS \\
\hline Fat (g) & 25 & 30.61 & 10.83 & 1.182 & 0.514 & NS \\
\hline Carbohydrate (g) & - & 139.86 & 32.18 & 3.511 & - & - \\
\hline Calcium (mg) & 400 & 728.04 & 420.09 & 45.83 & 0.776 & NS \\
\hline Iron (mg) & 18 & 14.089 & 7.43 & 0.810 & 0.523 & NS \\
\hline
\end{tabular}

S.D - Standard deviation

NS - Not significant

S.E. - Standard error of mean 
3. Desilva, DA, Yamoo M, Wickramasinghe, G Effects of tsunami on fisheries and coastal livelihood: Case study of tsunami ravaged southern Srilanka. Disasters. 2007; 31(4):386-404.

4. Schuffenecker et al. Genome Micro evaluation of chickungunya viruses causing the Indican Ocean outbreak. Resources of chickungunya. 2006. Vol Page missing.

5. Chastel C. Assessing epidemiological consequences two years after the tsunami of 26 December 2004. Bull. Soc. Pathol. Exot. 2007; 100(2):139-44.

6. Delpauch et al. Economic crisis and malnutrition: socioeconomic determinants of anthropometric status of preschool children. Public Health Nutr. 2000 May; 7 (3):385.

7. Singh et al. Childhood illness and malnutrition in under five children in drought affected district area of western Rajasthan. Journal of community dis. 2005 Mar; 38(1):88-96.

8. Mc Laren, DS. Skin in protein energy malnutrition. Arch Dermatol. 1987; 123(12):1674-1676a.
9. Joshi. Risk factors for protein energy malnutrition in preschool children. Re. Paul. Med. 2005 Mar - Apr; 116 Pp:1654-1660.

10. Park K. Park's text book of preventive and social medicine $20^{\text {th }}$ edition, Banarsidas Bhanot Publisher, Jabalpur, 2009:470-471.

11. Dey I and Chauduhri RN. Gender inequality in nutirional status among under five children in a village in Hooghly district, West Bengal. Ind. J Public Health. 2008; 2(4):218-20.

12. Brahmam SNV. National Nutrition Monitoring Bureau in India An overview, Indian J. Comm. Med. 2007; Vol. 32. Page missing.

13. Gupta MC and Mahajan BK"Text book of preventive and social medicine" $3^{\text {rd }}$ edition, Jaypee brothers Medical publishers, New Delhi; 2003.

14. Behrman RE. "Nelson Text Book of Pediatrics", W.B. Saunders publishing Co., Philadelphia ; (2004). Page missing.

15. Babicz et al. "Assessment of nutrition of seamen and fisher men" Eur J. Clin. Nutr. 1996 Aug ; 50 (8) Page missing.

16. Gopalan et al. "Nutritive value of Indian Foods" National institute of Nutrition, ICMR, Hyderabad. Page missing. 